\title{
Clinical characteristics and outcomes of hospitalized COVID-19 patients with diabetes: A multi-center, retrospective study in Turkey
}

\section{Hastanede yatan diyabetik COVID-19 hastalarının klinik özellikleri ve sonuçları: Türkiye'de çok merkezli, retrospektif bir çalışma}

Fatih Türrker ${ }^{1}$, Süileyman Ahbab ${ }^{1}$, Betüil Çavuşoğlu Türker ${ }^{2}$, Hayriye Esra Ataoglu ${ }^{1}$,Savaş Öztürk ${ }^{3}$

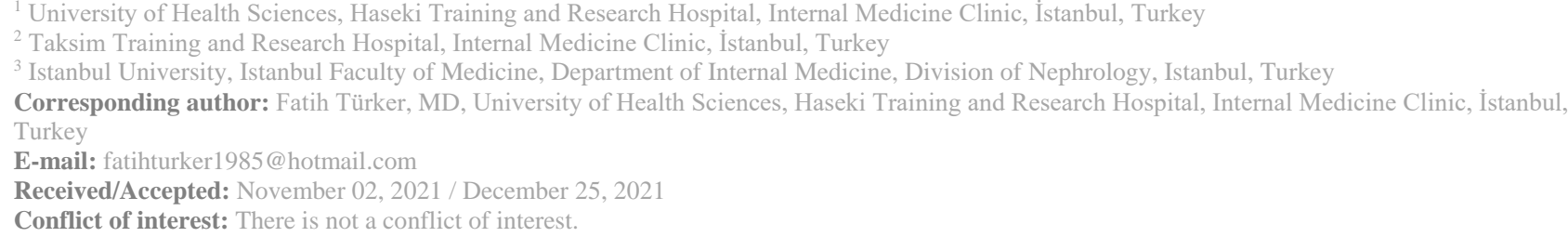

\section{SUMMARY}

Objective: Diabetes mellitus is known as one of the potential risk factors for severe COVID-19. This study it was aimed to evaluate and compared demographic, clinical and laboratory findings,mortality and outcomes of hospitalized diabetic and non-diabetic COVID-19 patients.

Method: The data of all consecutive adult patients admitted to the pandemic units of the participating hospitals' internal medicine clinics with the diagnosis of Covid-19 disease were gathered between April 20th 2020 and July 23th 2020.Only swab or serological tests positive patients were included in the study.Patients with clinical and/or radiological findings were considered to have Covid-19 disease and those having negative swab tests were excluded.The clinical characteristics, treatment and discharge outcomes and laboratuary tests of the patients at presentation were divided into two groups and compared as diabetic and non-diabetic COVID-19 patients.

Results: The median age was 52 years. There were 226 diabetic $(21.2 \%)$ and $839(78.8 \%)$ non-diabetic patients.Diabetic patients were older than nondiabetics . Chronic diseases in the group of diabetic patients were found to be significantly higher than non-diabetic patient group $(\mathrm{p}<0,001)$. There was no significant difference in major symptoms such as dry cough,fatigue fever between two groups.Percentage of anorexia was significantly elevated in the diabetic group $(\mathrm{p}<0,001)$.In diabetic group, baseline (at the time of diagnoses) serum eGFR,hemoglobin levels were decreased and sedimentation, $C R P$,procalcitonin,D-dimer were elevated than nondiabetic group ( $\mathrm{p}<0,001, \mathrm{p}=0,009, \mathrm{p}:<0.001, \mathrm{p}<0.001, \mathrm{p}<0.001, \mathrm{p}=0.029$ respectively). Admission to the intensive care unit and mortality were increased in diabetic patients group. $(\mathrm{p}<0.001)$

Conclusions: Diabetes are associated with increased complications, prolonged hospital stay, and mortality in COVID-19 patients.

Keywords: COVID 19, Diabetes Mellitus, clinical characteristics and outcomes.

(D) Fatih Türker
(D) Süleyman Ahbab
(ID) Betül Çavuşoğlu Türker
(D) Hayriye Esra Ataoglu
(D) Savaş Öztürk

ORCID IDs of the authors: F.T. 0000-0002-8281-0319 S.A. 0000-0001-9239-9132 B.C..T. 0000-0002-8041-1904 H.E.A. 0000-0002-6559-2575 S.Ö. 0000-0002-6259-6132 
ÖZET

Amaç: Diyabet, şiddetli COVID-19 için potansiyel risk faktörlerinden biri olarak bilinmektedir. Bu çalı̧̧ada, hastaneye yatırılan diyabetik ve diyabetik olmayan COVID-19 hastalarının demografik, klinik ve laboratuvar bulguları, mortalite ve sonuçlarının değerlendirilmesi ve karşılaştırılması amaçlandı.

Yöntem: Hastanelerin dahiliye kliniklerinin pandemi servislerine Covid-19 hastalığ tanısı ile 20 Nisan 2020 ile 23 Temmuz 2020 tarihleri arasında yatırılan tüm yetişkin hastaların verileri incelendi. Sadece sürüntü veya serolojik testleri pozitif olan hastalar çalışmaya dahil edildi. Klinik ve/veya radyolojik bulguları olan hastalar Covid-19 hastalığı olarak kabul edildi ve sürüntü testi negatif olanlar çalışma dışı bırakıldı. Hastaların başvuru anında klinik özellikleri, tedavi ve taburculuk sonuçları ile laboratuvar testleri diyabetik ve diyabetik olmayan COVID-19 hastaları olarak iki gruba ayrılarak karşılaştırıldı.

Bulgular: Ortanca yaş 52 saptandı. Çalışmada 226 diyabetik (\%21.2) ve 839 (\%78.8) diyabetik olmayan hasta vardı. Diyabetik hastalar diyabetik olmayanlardan daha yaşlıydı. Diyabetik hasta grubunda kronik hastalıklar diyabetik olmayan hasta grubuna göre anlamlı derecede yüksek bulundu $(\mathrm{p}<0,001)$. İki grup arasında kuru öksürük, halsizlik, ateş gibi majör semptomlar açısından anlamlı fark yoktu. Anoreksi yüzdesi diyabetik grupta anlamlı olarak yüksekti ( $<<0,001)$. Diyabetik grupta başlangıç (tanı anında) serum eGFR, hemoglobin seviyeleri diyabetik olmayan gruba göre azalmış ve sedimantasyon, CRP, prokalsitonin, D-dimer yükselmiştir ( $\mathrm{p}<0,001, \mathrm{p}=0,009, \mathrm{p}:<0,001, \mathrm{p}<0,001, \mathrm{p}<0,001, \mathrm{p}=0,029$ sırasıyla). Diyabetik hasta grubunda yoğun bakıma yatış ve mortalite daha fazla saptandı. $(p<0,001)$

Sonuç: Diyabet, COVID-19 hastalarında artmış komplikasyonlar, uzamış hastanede kalış süresi ve mortalite ile ilişkilidir. Anahtar sözcükler: COVID 19, Diabetes Mellitus, klinik özellikler ve sonuçlar.

\section{INTRODUCTION}

Coronavirus disease 2019 (COVID-19) is a disease caused by a novel coronavirus called severe acute respiratory syndrome coronavirus 2 (SARS-CoV-2). The disease has spread all over the world and become pandemic ${ }^{1,2}$. The COVID-19 infection creates a complex situation for people with underlying comorbid diseases which are associated with increased morbidity and mortality ${ }^{3,4}$. Since diabetic patients are known to be more susceptible to infections, diabetes mellitus will increase the incidence of contagious diseases and related comorbidities. Diabetes mellitus is now known to be one of the most frequent comorbid disease (33.8\%) in hospitalized patients with COVID19 infection ${ }^{5}$. Besides diabetes, hypertension (17\%), cardiovascular (5\%) and respiratory diseases (2\%) are important health problems for these patients ${ }^{6,8}$. There is limited data on the characteristics and outcomes of COVID-19 patients with diabetes hospitalized in Turkey. It was aimed to evaluate and compare the demographic, clinical and laboratory findings, mortality, and outcomes of hospitalized diabetic and non-diabetic COVID-19 patients in this study.

\section{MATERIAL AND METHODS}

\section{Data source}

This multicenter cohort study was performed using the data collected from pandemic units of internal medicine clinics of 5 training and research hospitals in Istanbul. COVID-19 patients were hospitalized in pandemic units these internal medicine clinics. Ethics committee approval was received from the Health Sciences University Istanbul Haseki Training and Research Hospital Ethics Committee (Reference No: 44-2020). Informed consent was waived due to the global urgent data requirement. All the data were collected anonymously without including patient identification information.

\section{Study population, data collection}

The data of all consecutive adult patients admitted to the pandemic units of the participating hospitals' internal medicine clinics with the diagnosis of COVID-19 were gathered between April 20th 2020 and July 23th 2020. Only swab or serological tests positive (confirmed case) patients were included in the study. Patients with clinical and/or radiological findings were considered to have COVID-19 (possible case) and those having negative swab tests and/or serological tests were excluded. We included patients who fully recovered and were discharged, patients in the ICU, and deceased patients. Patients still in hospital pandemic clinics or hospitalized for other reasons were not included. Re-admissions were also not included. The patients data were recorded such as demographic information, history of chronic diseases, drugs used in the history, laboratory analyzes, complete blood count, erythrocyte sedimentation rate (ESR), serum creatinine, estimated glomerular filtration rate (eGFR) ,albumin, alanine aminotransferase (ALT), 
aspartate aminotransferase (AST), lactate dehydrogenase (LDH), creatinine kinase, amylase, lipase, C-reactive protein (CRP), ddimer, ferritin, hemoglobin, lymphocyte, platelet count, chest computed tomography (CT) findings, drugs used in the treatment of COVID-19, length of hospital stay, intensive care unit (ICU) admission, the common complications of COVID-19 and patients outcomes. All swab positive COVID-19 patients were screened by a chest computed tomography (CT) The clinical characteristics of the patients at presentation were divided into two groups and compared as diabetic and nondiabetic COVID-19 patients. Patients age, gender, chronic diseases, drugs used in the history, drugs used in the treatment of COVID19, presentation symptoms and duration between first symptom and diagnosis were recorded. Hemoglobin, platelet, sedimentation, creatinine, eGFR , AST, ALT, LDH, CK, ferritin, lymphopenia percentages at diagnosis were compared between the two groups. CRP, procalcitonin, $d$ dimer values at the time of diagnosis and chest CT (computed tomography) findings were categorized and compared between the two groups. Development of leukopenia (white blood cell count less than 4000/mm3), lymphopenia (lymphocyte count less than $1200 / \mathrm{mm} 3$ ), anemia (hemoglobin less than $10 \mathrm{~g} / \mathrm{dL}$ ), thrombocytopenia (platelet count less than $150.000 / \mathrm{mm} 3$ ), an increase in serum creatinine, AST, ALT, LDH, CK, ferritin (more than twice the upper limit of normal, compared to baseline values) and decrease in serum albumin (less than $3.0 \mathrm{~g} / \mathrm{dl}$ ) were recorded.

\section{Statistical Method:}

IBM SPSS Statistics for Windows (Version 25.0, IBM Corp., Armonk, NY, USA) was used for statistical analysis. Categorical variables were given as number and percentage, and numerical variables were given as median and interquartile range (25th-75th percentile). The recorded parameters were compared between survivors vs. non-survivors, and between nonsurvivors/or patients still in the ICU vs. those discharged. The chi-square test was used for the comparisons of categorical variables. The student's t-test was used to compare two independent groups in the analyses of normally distributed numerical data. In the case of abnormal distribution of numerical data, the Mann-Witney-U test was used to compare the two groups. Cox regression analysis (with
Backward LR selection) was used in survival analyzes. Parameter found to be different between outcomes (non-survivor vs. survivor patients, and non-survivors/or those still in the ICU vs. discharged) were included in the regression models to find out parameters showing independent relationship with these outcomes. A p-value of less than 0.05 was considered significant.

\section{RESULTS}

This study was consisted of 1917 patients from 5 centers who were treated by hospitalization between 20th April 2020 and 23rd July 2020. COVID-19 PCR swab tests were positive in $1065(55.5 \%)$ of 1899 patients. Patients with a positive PCR were included in the study. The median age was 52 (IQR: 38-63) years. There were 226 diabetic $(21.2 \%)$ and $839(78.8 \%)$ non-diabetic patients. $109(48.2 \%)$ of these cases were male and $117(51.8 \%)$ were female. $(\mathrm{p}<0,001)$ Diabetic patients (median: 59) were older than nondiabetics (median: 49). Chronic diseases in the group of diabetic patients (Hypertension, Ischemic Heart Disease, Heart Failure, Chronic Kidney Disease, Chronic obstructive pulmonary disease, Cardiovascular Disease) were found to be significantly higher than non-diabetic patient group $(\mathrm{p}<0,001)$. Insulin, Oral Antidiabetics, Statin use was found to be significantly higher in the diabetic group in the medical history. $(\mathrm{p}<0,001)$ (Table $1)$. There was no significant difference in major symptoms such as dry cough, fatigue fever between two groups. Percentage of anorexia was significantly elevated in the diabetic group $(p<0,001)$. Percentage of symptomatic patients at the time of diagnosis was found significantly elevated in the diabetic group, $(\mathrm{p}<0,001)$. Asymptomatic disease at diagnosis COVID-19 was significantly higher in the non-diabetic group. ( $\mathrm{p}<0,001$ ). Moderate-to-severe disease was significantly higher in diabetic COVID-19 patients. In chest CT, single lesion was more common assigned in the non-diabetic group. $(\mathrm{p}<0,001)$. Ground glass opacity and bilateral multiple lesion was significantly elevated in the diabetic group according to chest CT results, ( $p: 0.008),(p<0,001)$. Normal findings on chest computed tomography are higher than non diabetic COVID-19 patients. $(\mathrm{p}<0,001)$ ( Table 2 ). In diabetic group, baseline (at the time of diagnoses) serum eGFR, hemoglobin levels were decreased and sedimentation, CRP, procalcitonin, D-dimer were elevated than 
nondiabetic group $(\mathrm{p}<0,001, \quad \mathrm{p}=0,009$, $\mathrm{p}:<0.001, \quad \mathrm{p}<0.001, \quad \mathrm{p}<0.001, \quad \mathrm{p}=0.029$ respectively) (Table3). Anticoagulant, vitamin supplementation, antibiotics, favipiravir/lopinavir and ritonavir treatments were found more frequently in the diabetic hospitalized group. $(\mathrm{p}<0.002, \mathrm{p}<0.001$, $\mathrm{p}<0.001, \mathrm{p}<0.001) .11(4.9 \%)$ patients in the diabetic group and $13(1.5 \%)$ patients in the non-diabetic group were non-survived. Admission to the intensive care unit were 11 (4.9\%) patients in diabetic and $15(1.8 \%)$ were in the non-diabetic group. Admission to the intensive care unit and mortality were increased in diabetic patients group, $\mathrm{p}<0.001$.It was observed anemia (hemoglobin less than 10 $\mathrm{g} / \mathrm{dL}$ ), an increase in serum creatinine, sedimentation, $\mathrm{LDH}, \mathrm{CK}$, arrhythmia and decrease in serum albumin (less than $3.0 \mathrm{~g} / \mathrm{dl}$ ) in during hospitalization in diabetic group (Table 5) .Cox Regression Analysis of Factors determining exitus and/or ICU in diabetic patients were evaluated. Gender (male), heart failure, moderate-to-severe disease at the time of diagnosis, low albumin and secondary bacterial infection during hospitalization were found to increase mortality in diabetics (Table $6)$.

\section{DISCUSSION}

Co-morbid diseases such as diabetes are associated with increased complications, prolonged hospital stay, and mortality in COVID-19 patients ${ }^{8,10}$. In this study, we found the mortality and ICU rate of diabetic COVID19 cases was approximately $9.8 \%$. These rates are higher than those observed in the general population with COVID-19 ${ }^{11}$. Several theories exist for the role of hyperglycemia in the viral respiratory infections. Elevated glucose levels may negatively affect pulmonary function, suppress the immune system and increasing the production of inflammatory cytokines 12,15. Considering all this ;in this study ; diabetic patients (median: 59) were older than nondiabetics (median: 49). Chronic diseases in the group of diabetic patients (Hypertension, Ischemic Heart Disease, Heart Failure, Chronic Kidney Disease, Chronic obstructive pulmonary disease, Cardiovascular Disease) were found to be significantly higher than nondiabetic patient group. In diabetic group, baseline (at the time of diagnoses) serum eGFR, hemoglobin levels were decreased and sedimentation, CRP, procalcitonin, D-dimer were elevated than nondiabetic group. As a result, moderate -to -severe disease were seen significantly higher in diabetic COVID-19 patients. For all that there was no significant difference in major symptoms such as dry cough, fatigue fever between two group. This may indicate that diabetes mellitus increases risk of bad prognosis in COVID-19 patients ${ }^{14}$ . As a sign that; in this study development of anemia, doubling of creatinine, LDH and lowering of albumin below $3.0 \mathrm{~g} / \mathrm{dl}$ and development of arrhythmia and muscle injury during hospitalization were statistically significantly more common in diabetic group than non-diabetic group patients. Likewise, chest computed tomography ground glass consolidations were significantly higher in the diabetic group. Anticoagulant use, vitamin supplementation ,macrolide and favipiravir/lopinavir-ritonavir use were found more frequently in the diabetic hospitalized group. All these findings support the relationship between diabetes and poor prognosis in COVID-19 patients ${ }^{17}$. In accordance, admission to the intensive care unit and exitus was seen higher in diabetics in this study . According to Cox regression analysis, when the factors determining the admission and/or hospitalization of diabetic patients to the intensive care unit are evaluated, the results obtained give us data about the parameters that affect the severity of COVID-19 in diabetic patients. Male gender, heart failure, moderate to severe disease, hypoalbuminemia, and presence of secondary bacterial infection were associated with poor prognosis in diabetics. This findings are consistent with the results of the study by Sridharan Raghavan et al. ${ }^{18}$. Considering the mortality of diabetic COVID-19 patients; clinical presentation and laboratory findings should be closely monitored and followed. Considering all these results; diabetes mellitus will increase the COVID-19 mortality and related comorbidities ${ }^{19}$.

\section{CONCLUSION}

This retrospective study showed that patients had diabetes will increase severity of COVID19. Although these finding are interesting, caution should be used in the interpretation of these results and more comprehensive studies on large populations are needed. 
Tablo 1:Baseline Characteristics of Diabetic and Nondiabetic COVID-19 Patients

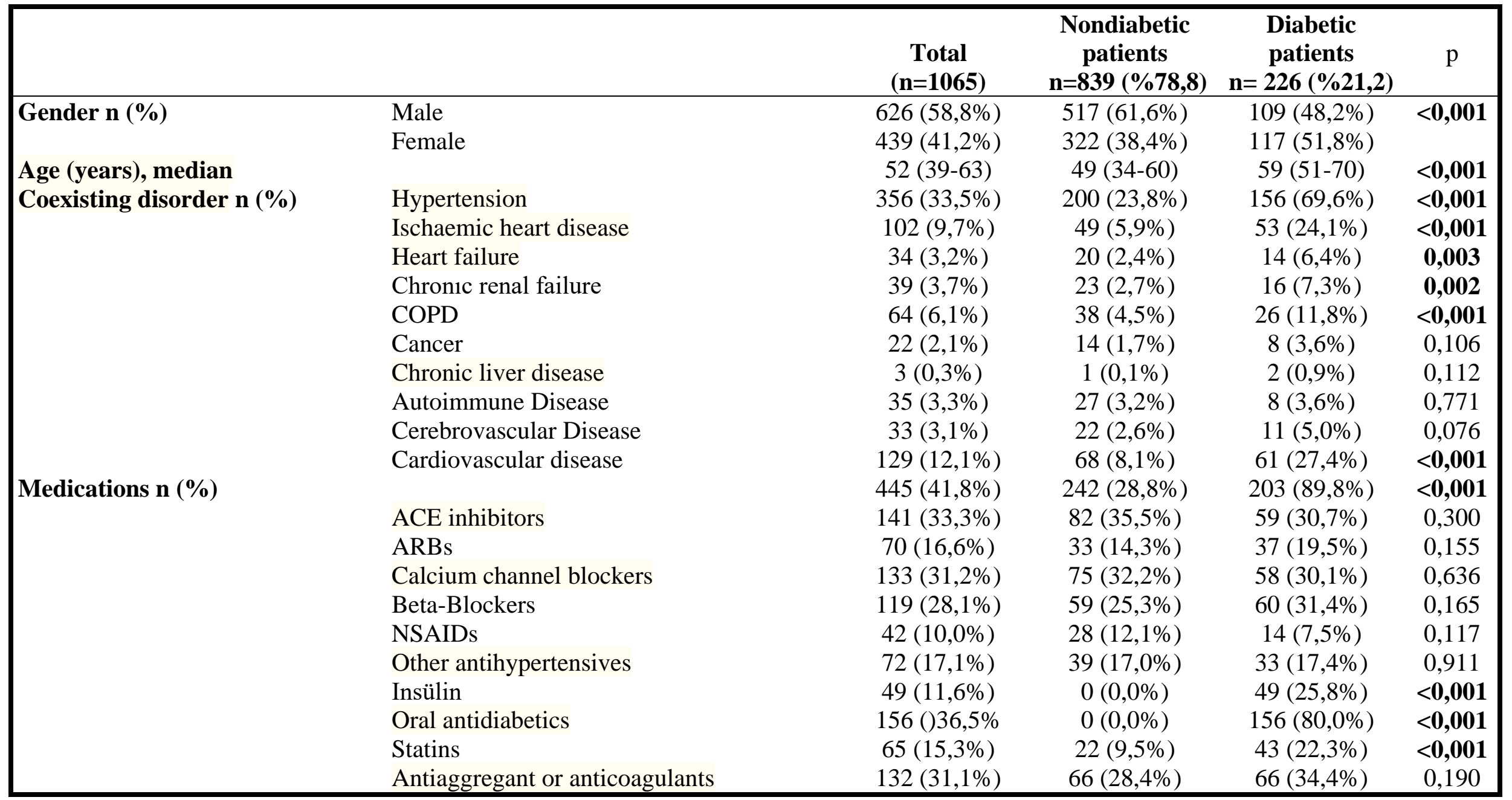


Abbreviations : COPD, Chronic obstructive pulmonary disease ;ACE, Angiotensin-converting enzyme; ARBs, Angiotensin II receptor blockers; NSAIDs,

Non-steroidal anti-inflammatory drugs ; Note: *Statistically significant variables $(\mathrm{p}<0.05)$.

Table 2:Symptoms And Clinic Signs of Diabetic and Nondiabetic COVID-19 Patients

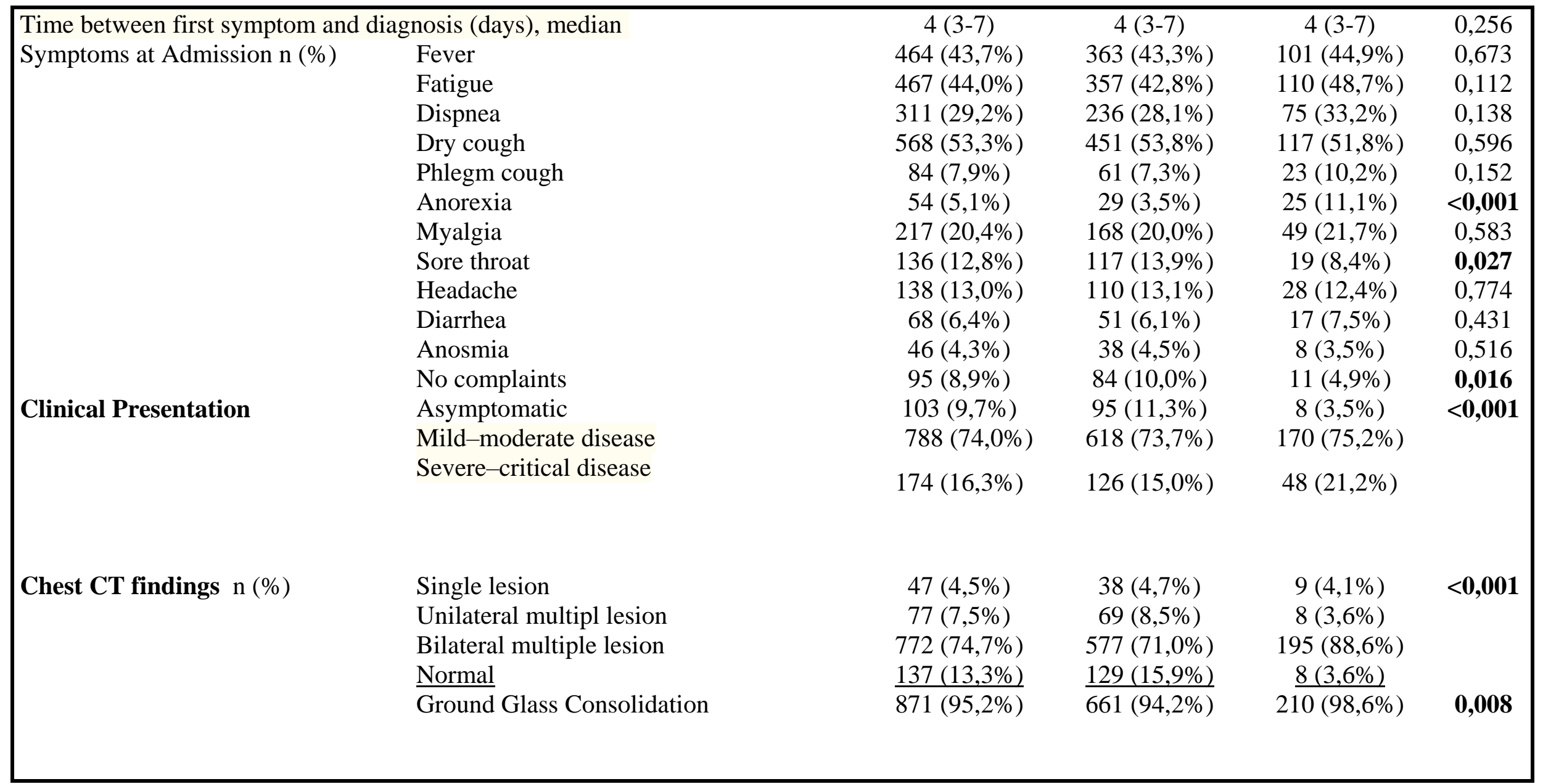

Note: *Statistically significant variables $(\mathrm{p}<0.05)$. 
Tablo 3: Laboratory Results At the Time Of The Diagnose Diabetic and Nondiabetic COVID-19 Patients

\begin{tabular}{|c|c|c|c|c|c|}
\hline \multirow[t]{10}{*}{ Laboratory findings, median } & Hemoglobin $(\mathrm{G} / \mathrm{Dl})$ & $13,3(12-14,6)$ & $13,6(12,3-14,7)$ & $12,5(11,4-13,6)$ & $<0,001$ \\
\hline & Neutrophil (/Mm3) & $3760(2680-5225)$ & $3730(2660-5070)$ & $3915(2708-5623)$ & 0,210 \\
\hline & Platelet (X1000/Mm3) & $205(160-258)$ & $204(160-251)$ & $\begin{array}{c}208,5(163- \\
283,25)\end{array}$ & 0,206 \\
\hline & Creatinine $(\mathrm{Mg} / \mathrm{Dl})$ & $0,86(0,70-1,04)$ & $0,86(0,71-1,02)$ & $0,85(0,70-1,12)$ & 0,568 \\
\hline & eGFR Median (IQR) & $\begin{array}{c}107,4(78,2- \\
149,7)\end{array}$ & $\begin{array}{c}108,1(80,6- \\
150,8)\end{array}$ & $\begin{array}{c}104,2(61,8- \\
149,1)\end{array}$ & $\mathbf{0 , 0 0 9}$ \\
\hline & Alt (Iu/L) & $25(17-39)$ & $25(17-39)$ & $25(16,5-39)$ & 0,836 \\
\hline & $\mathrm{Ldh}(\mathrm{Iu} / \mathrm{L})$ & $315(238-421)$ & $318(238,5-422)$ & $305(238-418,5)$ & 0,366 \\
\hline & $\mathrm{Ck}(\mathrm{Iu} / \mathrm{L})$ & $84(56-164)$ & $84(57-160)$ & $81(52,5-179)$ & 0,691 \\
\hline & Amylase $(\mathrm{Iu} / \mathrm{L}))$ & $58(46-78,3)$ & $58(47-79)$ & $60(44,3-77)$ & 0,933 \\
\hline & Ferritin $(\mathrm{ng} / \mathrm{ml})$ & $172(85,5-353,25)$ & $169(82,1-353,5)$ & $183(99,2-360,2)$ & 0,230 \\
\hline Lymphopenia $\mathrm{n}(\%)$ & & $402(37,7 \%)$ & $317(37,8 \%)$ & $85(37,6 \%)$ & 0,962 \\
\hline \multirow{2}{*}{ CRP, $n / N(\%)$ (> × upper limit) } & $10-20$ & $162(15,2 \%)$ & $110(13,1 \%)$ & $52(23,0 \%)$ & \\
\hline & $>20$ & $136(12,8 \%)$ & $94(11,2 \%)$ & $42(18,6 \%)$ & \\
\hline \multirow[t]{2}{*}{ Procalsitonin $\mathrm{n}(\%)$} & Normal & $789(85,2 \%)$ & $646(88,1 \%)$ & $143(74,1 \%)$ & $<0,001$ \\
\hline & High & $137(14,8 \%)$ & $87(11,9 \%)$ & $50(25,9 \%)$ & \\
\hline \multirow[t]{2}{*}{ D dimer $n / N(\%)(>\times$ upper limit $)$} & Normal & $580(57,0 \%)$ & $477(59,3 \%)$ & $103(48,4 \%)$ & 0,011 \\
\hline & $1-<3$ & $272(26,7 \%)$ & $200(24,9 \%)$ & $72(33,8 \%)$ & \\
\hline
\end{tabular}


$>3$

$165(16,2 \%)$

$127(15,8 \%)$

$38(17,8 \%)$

Abbreviations : eGFR, estimates glomerular filtration rate ; AST, aspartate aminotransferase; ALT, alanine aminotransferase ; LDH, Lactate dehydrogenase;CK, Creatinine Kinase .Note: *Statistically significant variables $(p<0.05)$.

Table 4: Treatment And Discharge Outcomes Of Diabetic and Nondiabetic COVID-19 Patients

\begin{tabular}{|c|c|c|c|c|c|}
\hline \multirow[t]{8}{*}{ Drug treatments, $n / N(\%)$} & Oseltamivir] & $537(50,4 \%)$ & $412(49,1 \%)$ & $125(55,3 \%)$ & 0,098 \\
\hline & Macrolides & $734(69,0 \%)$ & $555(66,2 \%)$ & $179(79,6 \%)$ & $<0,001$ \\
\hline & Hydroxychloroquine & $1041(97,8 \%)$ & $824(98,3 \%)$ & $217(96,0 \%)$ & 0,066 \\
\hline & Favipiravir & $275(25,8 \%)$ & $194(23,1 \%)$ & $81(36,0 \%)$ & $<0,001$ \\
\hline & Lopinavir-Ritonavir & $33(3,1 \%)$ & $19(2,3 \%)$ & $14(6,2 \%)$ & 0,001 \\
\hline & Glucocorticoids & $44(4,1 \%)$ & $30(3,6 \%)$ & $14(6,2 \%)$ & 0,079 \\
\hline & Tocilizumab & $17(1,6 \%)$ & $13(1,5 \%)$ & $4(1,8 \%)$ & 0,768 \\
\hline & Vitamin Supplement & $308(28,9 \%)$ & $220(26,2 \%)$ & $88(38,9 \%)$ & $<0,001$ \\
\hline \multirow{2}{*}{\multicolumn{2}{|c|}{$\begin{array}{l}\text { Any side effects related to these } \\
\text { drugs, } n / N(\%) \\
\text { ICU admission, } n / N(\%)\end{array}$}} & $30(3,1 \%)$ & $27(3,5 \%)$ & $3(1,6 \%)$ & 0,174 \\
\hline & & $67(6,3 \%)$ & $38(4,5 \%)$ & $29(12,8 \%)$ & $<0,001$ \\
\hline \multicolumn{2}{|c|}{ Length of stay at hospital, day, median } & $9(6-14)$ & $9(6-14)$ & $9(6-12,25)$ & 0,529 \\
\hline Exitus n $(\%)$ & & $24(2,3 \%)$ & $13(1,5 \%)$ & $11(4,9 \%)$ & $\mathbf{0 , 0 0 3}$ \\
\hline
\end{tabular}

Abbreviations : NSAIDs, Non-steroidal anti-inflammatory drugs ;ICU, intensive care unit Note: *Statistically significant variables ( $\mathrm{p}<0.05$ ). 
Table 5: Laboratory Tests During Hospitalization

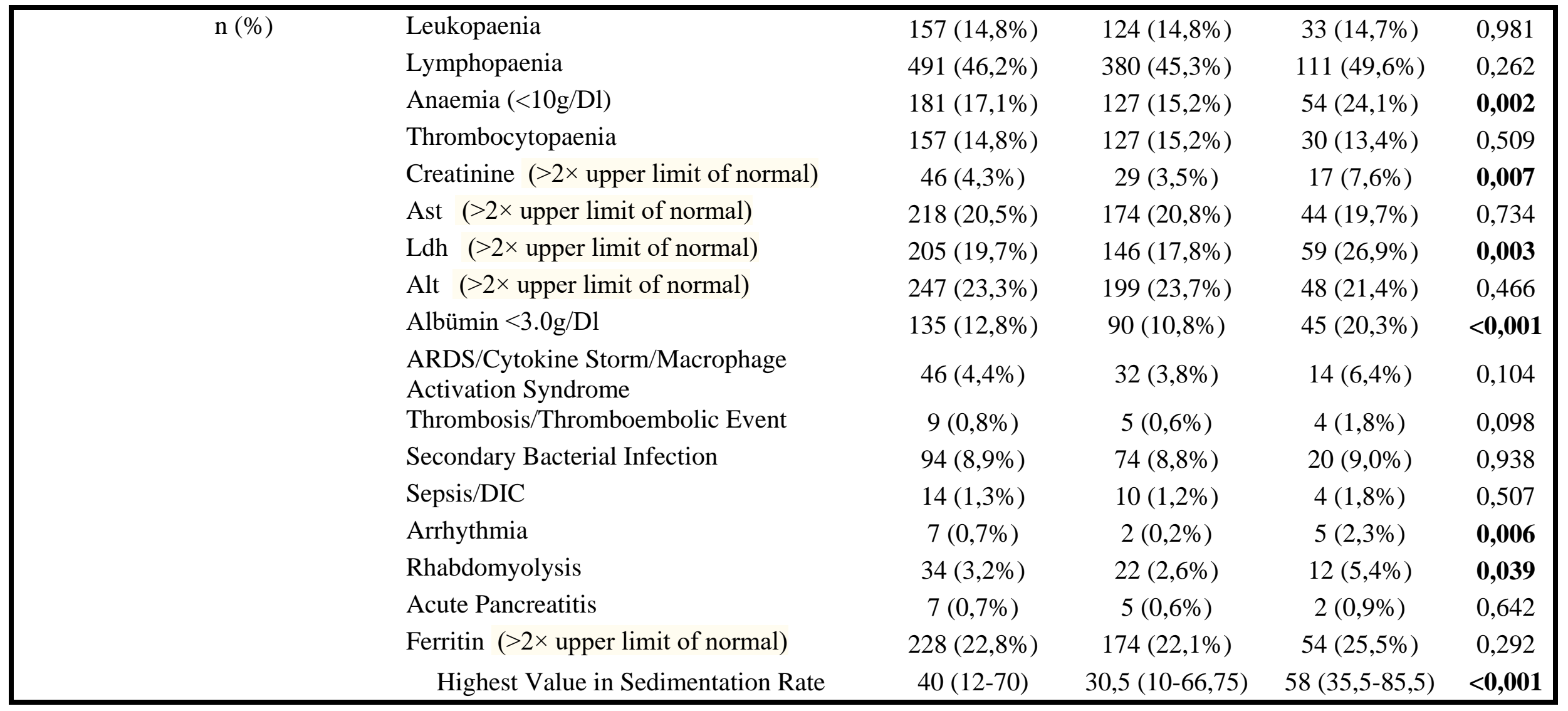

Abbreviations : AST, aspartate aminotransferase; LDH, Lactate dehydrogenase ;ALT, alanine aminotransferase ; ARDS, Acute respiratory distress syndrome; DIC, Disseminated intravascular coagulation; Note: *Statistically significant variables $(\mathrm{p}<0.05)$. 
Table 6: Cox Regression Analysis Of Factors determining exitus and/or ICU in diabetıc COVID-19 patients

\begin{tabular}{|lcccc|}
\hline & $\mathbf{p}$ & HR & \multicolumn{2}{c|}{$\% 95 \mathbf{C l}$} \\
Gender (Male) & $\mathbf{0 , 0 0 3}$ & 0,350 & 0,174 \\
Heart failure & $\mathbf{0 , 0 0 1}$ & 4,396 & 1,881 & 10,705 \\
Moderate to Severe illness & $\mathbf{0 , 0 0 0}$ & 3,870 & 1,834 \\
Elevated Prokalsitonin & 0,072 & 0,474 & 0,210 \\
Hypoalbuminemia & $\mathbf{0 , 0 0 4}$ & 2,951 & 1,406 & 1,070 \\
Secondary bacterial infection & $\mathbf{0 , 0 0 1}$ & 3,561 & 1,661 & 7,632 \\
\hline
\end{tabular}

Note: *Statistically significant variables $(\mathrm{p}<0.05)$. 


\section{REFERENCES}

1. Wang C, Horby PW, Hayden FG, Gao GF. A novel coronavirus outbreak of global health concern. Lancet. 2020;395:470-473.

2. Huang C, Wang Y, Li X, Ren L, Zhao J, Hu Y, Zhang L, Fan G, Xu J, Gu X, Cheng Z, Yu T, Xia J, Wei Y, Wu W, Xie X, Yin W, Li H, Liu M, Xiao Y, Gao H, Guo L, Xie J, Wang G, Jiang R, Gao Z, Jin Q, Wang J, Cao B. Clinical features of patients infected with 2019 novel coronavirus in Wuhan, China. Lancet. 2020;395:497-506.

3.Garg S, Kim L, Whitaker M, O'Halloran A, Cummings C, Holstein R, Prill M, Chai SJ, Kirley PD, Alden NB, Kawasaki B, Yousey-Hindes K, Niccolai L, Anderson EJ, Openo KP, Weigel A, Monroe ML, Ryan P, Henderson J, Kim S, ComoSabetti K, Lynfield R, Sosin D, Torres S, Muse A, Bennett NM, Billing L, Sutton M, West N, Schaffner W, Talbot HK, Aquino C, George A, Budd A, Brammer L, Langley G, Hall AJ, Fry A. Hospitalization Rates and Characteristics of Patients Hospitalized with Laboratory-Confirmed Coronavirus Disease 2019 - COVID-NET, 14 States, March 1-30, 2020. MMWR Morb Mortal Wkly Rep. 2020;69:458-464.

4. Kobayashi T, Jung SM, Linton NM, Kinoshita R, Hayashi K, Miyama T, Anzai A, Yang Y, Yuan B, Akhmetzhanov AR, Suzuki A, Nishiura H. Communicating the Risk of Death from Novel Coronavirus Disease (COVID-19). J Clin Med 2020;9:580.

5. Richardson S, Hirsch JS, Narasimhan M, Crawford JM, McGinn T, Davidson KW; the Northwell COVID-19 Research Consortium, Barnaby DP, Becker LB, Chelico JD, Cohen SL, Cookingham J, Coppa K, Diefenbach MA, Dominello AJ, Duer-Hefele J, Falzon L, Gitlin J, Hajizadeh N, Harvin TG, Hirschwerk DA, Kim EJ, Kozel ZM, Marrast LM, Mogavero JN, Osorio GA, Qiu M, Zanos TP. Presenting Characteristics, Comorbidities, and Outcomes Among 5700 Patients Hospitalized With COVID-19 in the New York City Area. JAMA 2020;323:2052-9.

6. Yang J, Zheng Y, Gou X, Pu K, Chen Z, Guo Q, Ji R, Wang H, Wang Y, Zhou Y. Prevalence of comorbidities and its effects in patients infected with SARS-CoV-2: a systematic review and metaanalysis. Int J Infect Dis. 2020;94:91-95.

7. Huang C, Wang Y, Li X, Ren L, Zhao J, Hu Y, Zhang L, Fan G, Xu J, Gu X, Cheng Z, Yu T, Xia J, Wei Y, Wu W, Xie X, Yin W, Li H, Liu M, Xiao Y, Gao H, Guo L, Xie J, Wang G, Jiang R, Gao Z, Jin Q, Wang J, Cao B. Clinical features of patients infected with 2019 novel coronavirus in Wuhan, China. Lancet. 2020;395:497-506

8. Guan WJ, Ni ZY, Hu Y, Liang WH, Ou CQ, He JX, Liu L, Shan H, Lei CL, Hui DSC, Du B, Li LJ, Zeng G, Yuen KY, Chen RC, Tang CL, Wang T, Chen PY, Xiang J, Li SY, Wang JL, Liang ZJ, Peng YX, Wei L, Liu Y, Hu YH, Peng P, Wang JM, Liu JY, Chen Z, Li G, Zheng ZJ, Qiu SQ, Luo J, Ye CJ, Zhu SY, Zhong NS; China Medical Treatment Expert Group for Covid-19. Clinical Characteristics of Coronavirus Disease 2019 in China. N Engl J Med. 2020;382:1708-1720.

9. Yang X, Yu Y, Xu J, Shu H, Xia J, Liu H, Wu Y, Zhang L, Yu Z, Fang M, Yu T, Wang Y, Pan S, Zou X, Yuan S, Shang Y. Clinical course and outcomes of critically ill patients with SARS-CoV2 pneumonia in Wuhan, China: a single-centered, retrospective, observational study. Lancet Respir Med.2020;8:475-81.

10 Zhang JJ, Dong X, Cao YY, Yuan YD, Yang YB, Yan YQ, Akdis CA, Gao YD. Clinical characteristics of 140 patients infected with SARSCoV-2 in Wuhan, China. Allergy. 2020;75:17301741

11. Chen N, Zhou M, Dong X, Qu J, Gong F, Han Y, Qiu Y, Wang J, Liu Y, Wei Y, Xia J, Yu T, Zhang $X$, Zhang L. Epidemiological and clinical characteristics of 99 cases of 2019 novel coronavirus pneumonia in Wuhan, China: a descriptive study. The Lancet. 2020;395:507-13.

12. Hsia CCW, Raskin P. The diabetic lung: Relevance of alveolar microangiopathy for the

use of inhaled insulin. The American Journal of Medicine. 2005;118:205-11.

13. Goldman MD. Lung Dysfunction in Diabetes. Diabetes Care. 2003;26:1915-8.

14. Kiselar JG, Wang X, Dubyak GR, El Sanadi C, Ghosh SK, Lundberg K, Williams WM. Modification of $\beta$-Defensin-2 by Dicarbonyls Methylglyoxal and Glyoxal Inhibits Antibacterial and Chemotactic Function In Vitro. PLoS One. 2015; 10:e130533.

15. Knapp S. Diabetes and infection: is there a link?--A mini-review. Gerontology.

2013;59:99-104.

16. Onat A, Şenocak M, Örnek E, Gozukara Y, Şurdumavcı G, Karaaslan Y, Özışık U, İşler M, Taşkın V, Tabak F, Öz Ö, Özcan R . Survey on Prevalence of Cardiac Disease and its Risk Factors in Adults in Turkey: 3. Prevalence of Heart Diseases. Turk Kardiyol Dern Ars.1991; 19: 26-33 
17. Kumar A, Arora A, Sharma P, Anikhindi SA, Bansal N, Singla V, Khare S, Srivastava A. Is diabetes mellitus associated with mortality and severity of COVID-19? A meta-analysis. Diabetes Metab Syndr. 2020;14:535-545.

18. Raghavan S, Vassy JL, Ho YL, Song RJ, Gagnon DR, Cho K, Wilson PWF, Phillips LS.
Diabetes Mellitus-Related All-Cause and Cardiovascular Mortality in a National Cohort of Adults. J Am Heart Assoc. 2019;8:e011295

19. Berbudi A, Rahmadika N, Tjahjadi AI, Ruslami $\mathrm{R}$. Type 2 Diabetes and its Impact on the Immune System. Curr Diabetes Rev. 2020;16:442-449. 